\title{
ANALISIS PROSES BERPIKIR KREATIF DALAM PEMECAHAN MASALAH GEOMETRI BERDASARKAN GAYA KOGNITIF REFLEKTIF DAN IMPULSIF SISWA
}

\author{
Herianto $^{1}$, Nurqiyamah Hamid ${ }^{2}$ \\ STKIP YAPTI Jeneponto ${ }^{1,2}$ \\ antoherianto47@gmail.com ${ }^{1}$, qiyahamid@gmail.com²
}

Abstrak

Penelitian ini bertujuan untuk mendeskripsikan proses berfikir kreatif dalam memecahkan masalah geometri berdasarkan gaya kognitif reflektif dan gaya kognitif impulsif siswa. Penelitian ini adalah penelitian deskriptif dengan pendekatan kualitiatif. Subjek penelitian ini ditetapkan sebanyak 2 orang diantaranya: 1 orang siswa dengan gaya kognitif reflektif dan 1 orang siswa dengan gaya kognitif impulsif. Subjek penelitian ini ditentukan setelah melalui beberapa tahapan, diantaranya: 1) Menetapkan kelas penelitian yaitu kelas kelas VIII di MTs Al Amanah Kabupaten Jeneponto tahun ajaran 2020/2021, 2) Mengontrol kemampuan awal siswa berdasarkan tingkat kemampuannya dalam memecahkan masalah matematika, (3) Memberi tes Matching Familiar Figures Tes (MFFT). Data penelitian diperoleh melalui hasil Tes Pemecahan Masalah Kreatif (TPMK) dan wawancara terhadap subjek penelitian. Data kemudian dianalisis dengan langkahlangkah, yaitu: (1) Menelaah seluruh data yang tersedia dari berbagai sumber, (2) reduksi data, 3) Penyajian data, (4) Membuat coding, (5) Memaparkan data, dan (6) penarikan kesimpulan. Berdasarkan hasil penelitian ditemukan: (1) Subjek dengan gaya kogntif reflektif melalui proses berpikir dari tahap persiapan, inkubasi, illuminasi dan verifikasi; (2) Subjek dengan gaya kogntif reflektif menemukan idenya tanpa dipicu oleh keadaan sekelilingnya atau mengembangkan idenya untuk membangun cara baru dalam menyelesaikan masalah; (3) Subyek dengan gaya kognitif impulsif tidak melewati proses inkubasi dan illuminasi dalam memecahkan masalah geometri; (4) subjek dengan gaya kognitif impulsif menemukan idenya secara tiba-tiba dengan mengingat kembali konsep yang diajarkan oleh gurunya.

Kata Kunci: Berpikir Kreatif, Gaya Kognitif, Reflektif, Impulsif.

\section{A. Pendahuluan}

Pendidikan matematika pada hakekatnya mempunyai dua arah pengembangan yaitu untuk memenuhi kebutuhan masa kini dan masa datang. Kebutuhan masa kini mengarah pada kemampuan pemahaman konsep-konsep yang diperlukan untuk menyelesaikan masalah matematika dan ilmu pengetahuan lainnya. Sedangkan kebutuhan masa datang mengarah pada kemampuan nalar yang logis, sistematis, kritis, dan kreatif. Selain itu, pendidikan matematika mengasah 
kemampuan siswa untuk berpikir objektif dan terbuka dalam menghadapi masalah dalam kehidupan sehari-hari atau menghadapi masa depan yang selalu berubah (Simbolon, 2019). Hal tersebut sekaligus untuk menjawab hasil penelitian yang menyebutkan bahwa tingkat penguasaan matematika peserta didik di semua jenjang pendidikan masih tergolong rendah (Novita, 2018).

Dalam kasus yang lain, kemampuan siswa SMP/ MTs dalam menyelesaikan masalah terbuka cukup tinggi, sedangkan pada soal matematika yang menuntut penyelesaian masalah dengan menggunakan satu konsep metematika tergolong rendah (Mulyana, 2015). Selain itu, siswa cenderung enggan untuk mengerjakan permasalahan berupa soal-soal berpikir tingkat tinggi, bahkan menyerah terlebih dahulu sebelum mencoba menyelesaikan soal tersebut. Dari keadaan inilah, dibutuhkan pengetahuan terhadap faktor psikologis dan aktivitas mental siswa saat diperhadapkan dengan masalah matematika (Herianto, 2019).

Salah satu pengetahuan yang dimaksud adalah bagaimana mengetahui proses dari berpikir kreatif dari siswa. Berpikir kreatif adalah kemampuan untuk mengkonstruksi atau menghasilkan berbagai respon yang mungkin, ide-ide, opsiopsi atau alternatif-alternatif untuk suatu permasalahan atau tantangan (Dewi, 2013). Secara hiearkis posisi berpikir kreatif dalam tingkatan berpikir seseorang berada pada posisi puncak dan digolongkan sebagai proses berpikir tingkat tinggi. Hal ini secara jelas dapat dilihat pada gambar 1 berikut:

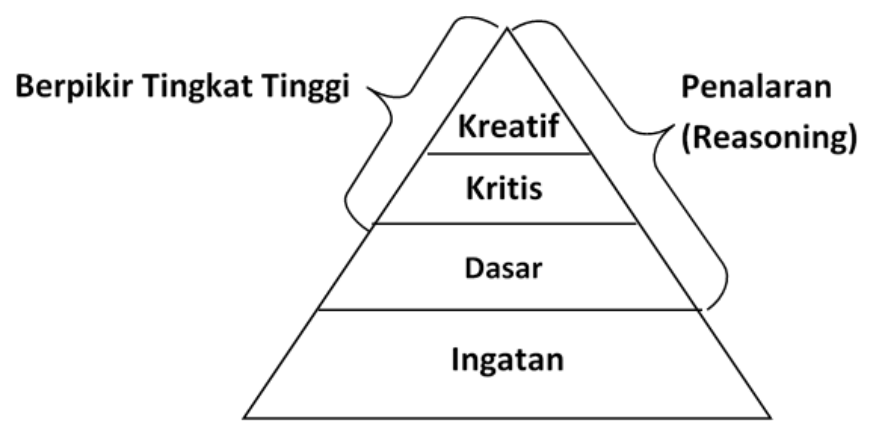

Gambar1. Hirarki berpikir menurut Krulik dan Rudnick (Januariawan, 2020).

Untuk mengetahui alur dari proses berpikir kratif siswa, penelitian ini mengacu pada proses berpikir reatif model Wallas (Sari, 2017) yaitu: 
Tabel 1. Rumusan Indikator Proses Berpikir kreatif

\begin{tabular}{|c|c|}
\hline $\begin{array}{l}\text { Tahapan Berpikir } \\
\text { Kreatif }\end{array}$ & Indikator \\
\hline Persiapan & $\begin{array}{l}\text { - } \text { Mencermati masalah } \\
\text { - } \text { Memahami/menemukan masalah } \\
\text { - } \text { Mensintesis ide } \\
\text { - Merenbangun ide/gagasan } \\
\end{array}$ \\
\hline Inkubasi & $\begin{array}{l}\text { - } \text { Mengerami/mengendapkan informasi/masalah } \\
\text { - } \text { Mengendorkan upaya berpikir } \\
\text { - Kelihatan tidak berpikir, namun pikirannya sedang menata } \\
\text { fakta-fakta atau konsep-konsep yang dia pahami untuk } \\
\text { menemukan suatu ide }\end{array}$ \\
\hline Illuminasi & $\begin{array}{ll}\text { - } & \text { Membangun ide/gagasan } \\
\text { - } & \text { Merencanakan implementasi ide/ gagasan/cara } \\
\end{array}$ \\
\hline Verifikasi & $\begin{array}{l}\text { - Merencanakan implementasi ide/ gagasan/cara } \\
\text { - Mengimplementasikan ide }\end{array}$ \\
\hline
\end{tabular}

Proses berpikir kreatif tersebut dipengaruhi banyak faktor, salah satunya adalah kondisi kognitif siswa. Dalam hal, gaya kognitif perlu dipertimbangkan. Gaya kognitif menurut Goldstein adalah karakteristik individu dalam usaha mengorganisasikan lingkungan secara konseptual (Prasetyowati, 2019). Dalam pengertian lain, gaya kognitif sebagai pendekatan untuk menerima, mengingat, dan berpikir yang cenderung digunakan individu untuk memahami lingkungannya (Syawahid, 2018).

Dalam proses pembelajaran, anak yang impulsif akan mengambil keputusan dengan cepat tanpa memikirkannya secara mendalam. Sebaliknya, anak yang reflektif mempertimbangkan segala alternatif sebelum mengambil keputusan dalam situasi yang tidak mempunyai penyelesaian masalah (Nasriadi, 2019). Jadi seorang reflektif atau impulsif bergantung pada kecenderungan untuk merefleksi tau memikirkan alternatif kemungkinan pemecahan suatu masalah yang bertentangan dengan kecenderungan untuk mengambil keputusan yang impulsif dalam menghadapi masalah-masalah yang sangat tidak pasti jawabannya. 
Ada dua aspek penting yang harus diperhatikan dalam mengukur reflektif dan impulsif, yaitu banyaknya waktu yang diperlukan untuk memecahkan masalah dan keakuratan jawaban yang diberikan. Jika aspek waktu dibedakan menjadi dua yaitu singkat dan lama, serta aspek keakuratan jawaban dibedakan menjadi dua yaitu akurat/cermat (keakuratan tinggi) dan tidak akurat/tidak cermat (keakuratan rendah), maka siswa dapat dikelompokkan menjadi empat kelompok, yaitu: kelompok siswa yang menggunakan waktu singkat dalam menjawab dan jawaban yang diberikan cermat/benar, kelompok siswa yang menggunakan waktu singkat dalam menjawab namun tidak cermat (impulsif), kelompok siswa yang menggunakan waktu lama dalam menjawab tetapi jawaban yang diberikan cermat (reflektif), dan kelompok siswa yang menggunakan waktu lama dalam menjawab dan jawaban yang diberikan tidak cermat (Purnomo, 2015).

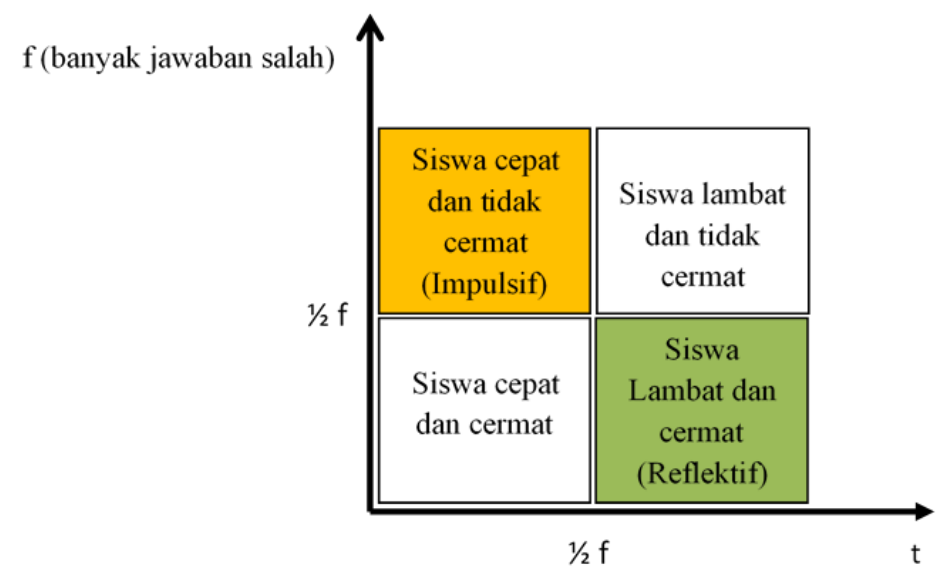

Gambar 2 Pengelompokan siswa reflektif dan impulsif berdasarkan $t$ (waktu menjawab) dan $\mathrm{f}$ (banyak jawaban salah)

Aktivitas berpikir kreatif merupakan proses yang diperlukan ketika seseorang sedang berada dalam keadaan kritis dimana ia sedang berusaha memecahkan suatu masalah yang rumit dan memerlukan cara-cara penyelesaian yang tidak seperti biasanya.

\section{B. Metode Penelitian}

Penelitian ini adalah penelitian deskriptif dengan pendekatan kualitiatif. Penelitian dilaksanakan di Kelas VIII MTs Al Amanah Kabupaten Jeneponto. Subjek penelitian ini ditetapkan sebanyak 2 orang dengan asumsi 1 orang siswa dengan gaya kognitif reflektif dan 1 orang dengan gaya kognitif impulsif. Sebagai 
penelitian kualitatif, instrumen utama penelitian dalam penelitian ini adalah peneliti sendiri dibantu dengan Tes Pemecahan Masalah Matematika (TPMM), Matching Familiar Figures Tes (MFFT), Tes Pemecahan Masalah Kreatif (TPMK), dan pedoman wawancara.

Pelaksanaan penelitian diawali dengan memberikan Tes Pemecahan Masalah Matematika (TPMM) dan tes gaya kognitif yang dikenal nama MFFT (Matching Familiar Figure Test). Berdasarkan hasil tes tersebut, akan diperoleh subjek penelitian yaitu siswa yang bergaya kognitif impulsif dan siswa yang bergaya kognitif reflektif. Peneliti akan memilih masing-masing 1 siswa dengan gaya kognitif impulsif dan 1 siswa dengan gaya kognitif reflektif untuk selanjutnya diberikan tes kemampuan berpikir kreatif. Pada tahap berikutnya, kedua subjek diberikan Tes Pemecahan Masalah Kreatif (TPMK) dengan soal sebagai berikut:

\begin{tabular}{|l|}
\hline Diketahui persegi panjang berikut, \\
1) Buatlah sebanyak-banyaknya bangun datar persegi panjang lainnya, yang luasnya sama \\
dengan bangun datar persegi panjang di atas! \\
2) Gambarlah sebanyak-banyaknya bangun datar berbeda yang luasnya sama dengan bangun \\
datar persegi panjang di atas! \\
3) Tuliskan sebanyak-banyaknya langkah-langkah yang berbeda yang anda berikan dalam \\
menemukan salah satu bangun datar pada soal nomor 2 di atas!
\end{tabular}

Gambar 3 Soal Tes Pemecahan Masalah Kreatif (TPMK)

Hasil TPMK tersebut kemudian disandingkan dengan hasil wawancara eksploratif dengan subjek. Data kemudian direduksi dengan membuat rangkuman yang terdiri dari: inti, proses, pernyataan-pernyataan yang sesuai dengan tujuan penelitian. Kata-kata subjek yang tidak sesuai dengan tujuan penelitian dihilangkan. Validasi data dilakukan pada saat pengumpulan data berlangsung, yaitu dengan cara verifikasi. Pada penelitian ini verifikasi data yang digunakan adalah triangulasi teknik yaitu dengan mewawancarai sumber/subjek kemudian membandingkan dan memeriksa data hasil tes dan hasil wawancara.

\section{Hasil Dan Pembahasan}

Berdasarkan hasil TPMK untuk subjek dengan gaya kognitif impulsif, ditemukan hasil penelitian yang ditunjukkan melalui gambar 3 sebagai berikut: 


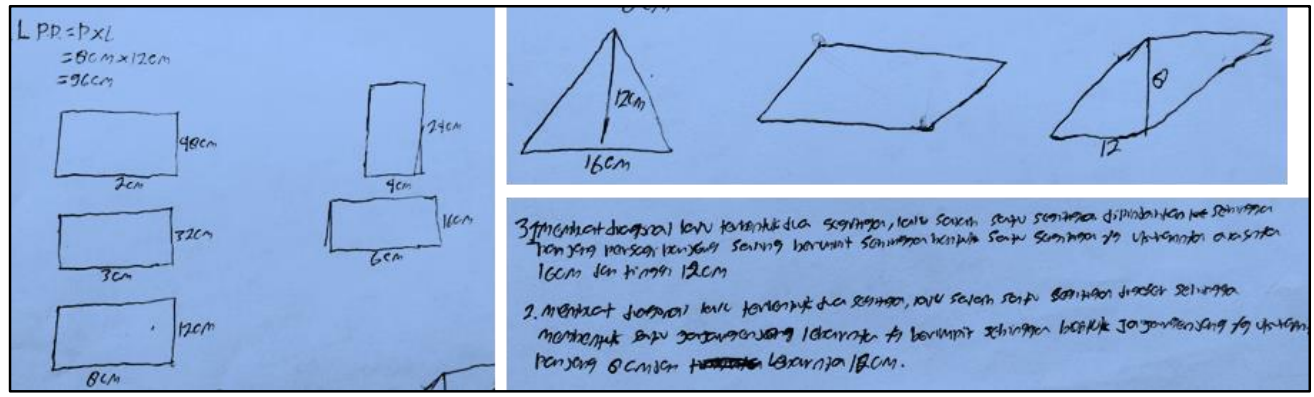

Gambar 4. Hasil TPMK Subjek dengan Gaya Kognitif Impulsif

Hasil tes tersebut didukung dengan hasil wawancara yang ditunjukkan melalui tabel 2 berikut:

Tabel 2 Hasil Wawancara Eksploratif dengan Subyek Bergaya Kognitif Impulsif

\begin{tabular}{|c|c|c|}
\hline No & $\begin{array}{c}\text { Tahapan Berpikir } \\
\text { Kreatif }\end{array}$ & Proses Berpikir Subjek \\
\hline 1 & Tahap Persiapan & $\begin{array}{l}\text { - Membaca soal } \\
\text { - } \text { Meal tes kemampuan berpikir kreatif ini adalah soal non rutin } \\
\text { soal tes kemampuan berpikir kreatif } \\
\text { - Mengaitkan informasi dari soal dengan konsep dan sifat bangun } \\
\text { datar persegi panjang } \\
\text { - Mempersiapkan penyelesaian soal dengan membaca soal, } \\
\text { menuliskan kembali keterangan soal yang diketahui, mencari luas } \\
\text { persegi panjang dan menuliskan rumus bangun datar yang } \\
\text { diketahuinya sebagai tahapan untuk menjawab pertanyaan soal } \\
\text { nomor } 1 \text { dan } 2 \\
\text { Mengerjakan soal dengan cara coba-coba yaitu dengan } \\
\text { menggambarkan bangun datar yang jika dioperasikan dengan } \\
\text { rumus luasnya masing-masing akan menghasilkan luas sebesar } 96 \\
\text { cm². } \\
\text { - Setelah tidak mampu menyelesaikan soal dengan cara coba- } \\
\text { coba, mengubah cara dengan membuat diagonal persegi panjang, } \\
\text { dan memikirkan untuk membentuk potongan persegi panjang } \\
\text { tersebut sehingga menghasilkan bangun datar segitiga dan jajar } \\
\text { genjang. }\end{array}$ \\
\hline 2 & Tahap Inkubasi & $\begin{array}{l}\text { - } \text { mengalami kejenuhan dan kebingungan mengerjakan soal } \\
\text { - berhenti memikirkan soal tes kemampuan berpikir kreatif saat } \\
\text { melakukan kegiatan lain }\end{array}$ \\
\hline 3 & Tahap Illuminasi & $\begin{array}{l}\text { - menemukan idenya secara tiba-tiba } \\
\text { - tidak memikirkan hal lain selain soal setelah menemukan idenya, } \\
\text { dalam hal ini tidak melalui tahap inkubasi } \\
\text { menemukan idenya, saat mencoba mengerjakan soal dan berusaha } \\
\text { mengingat konsep bangun datar yang pernah diajarkan oleh } \\
\text { gurunya }\end{array}$ \\
\hline 4 & Tahap Verifikasi & $\begin{array}{l}\text { - } \text { menguji kembali jawabannya } \\
\text { - tidak mampu mendapatkan jawaban yang lebih banyak dengan } \\
\text { menggunakan cara yang ditemukannya/diujinya }\end{array}$ \\
\hline
\end{tabular}


Adapun hasil TPMK dari subyek dengan gaya kognitif reflektif, ditunjukkan dalam gambar 4 berikut:

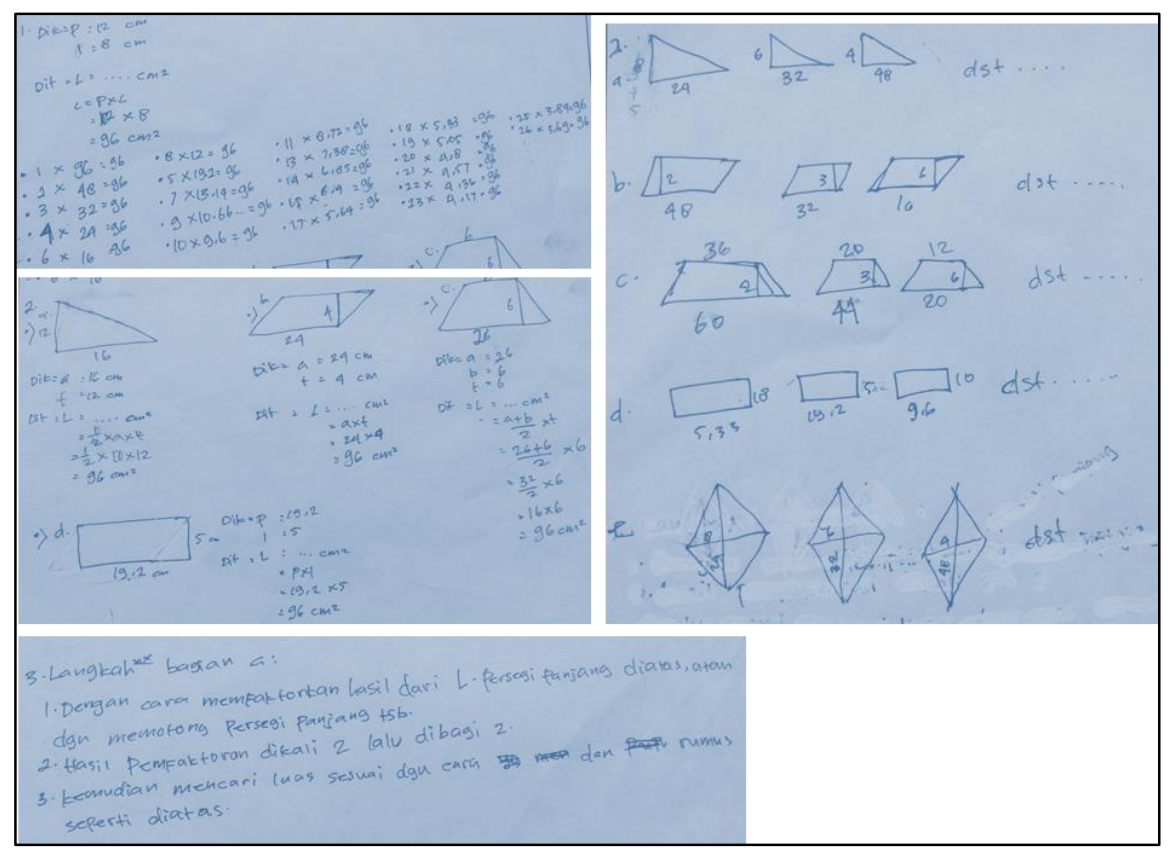

Gambar 5. Hasil TPMK Subjek dengan Gaya Kognitif Reflektif

Hasil tes tersebut didukung dengan hasil wawancara yang ditunjukkan melalui tabel 4 berikut:

Tabel 4 Hasil Wawancara Eksploratif dengan Subyek Bergaya Kognitif Reflektif

\begin{tabular}{|c|c|c|}
\hline No & $\begin{array}{l}\text { Tahapan Berpikir } \\
\text { Kreatif }\end{array}$ & Proses Berpikir Subjek \\
\hline 1 & Tahap Persiapan & $\begin{array}{l}\text { - } \\
\text { - } \text { baru pertama kali menemukan jenis soal yang diberikan. Dari } \\
\text { temuan ini, dapat disimpulkan bahwa soal tes kemampuan } \\
\text { berpikir kreatif ini adalah soal non rutin. } \\
\text { - mengolah infomasi pada soal nomor } 1 \text { dengan berusaha } \\
\text { mengingat kembali pelajaran tentang persegi panjang } \\
\text { - memulai menyelesaiakan masalahnya dengan cara coba-coba } \\
\text { yaitu mencari dua bilangan yang jika dikalikan menghasilkan } \\
\text { jawaban } 96 \\
\text { - Setelah tidak mampu menyelesaian masalahnya dengan cara } \\
\text { coba-coba, menyelesaiakan masalahnya dengan } \\
\text { menfaktorkan luas persegi panjang yang diketahui } \\
\text { menemukan cara penyelesaian masalah dengan pendekatan } \\
\text { rumus luas persegi panjang, menfaktorkan, dan konsep relasi }\end{array}$ \\
\hline 2 & Tahap Inkubasi & $\begin{array}{l}\text { - gelisah dan mulai jenuh mengerjakan soal } \\
\text { - } \quad \text { berhenti memikirkan soal saat melakukan kegiatan lain }\end{array}$ \\
\hline
\end{tabular}




\begin{tabular}{lll}
\hline 3 Tahap Illuminasi & - menemukan idenya secara tiba-tiba \\
& - menemukan idenya saat melakukan kegiatan lain \\
& - menemukan idenya saat tiba-tiba membayangkan \\
& pelajarannya tentang penfaktoran \\
& - kembali menemukan jawabannya yang lain saat tiba-tiba \\
& membayangkan jika rumus belah ketupat tidak jauh berbeda \\
& dengan persegi panjang \\
\hline - & menjadi yakin dengan ide yang ditemukannya dengan \\
& menguji kembali jawabannya \\
& mampu menerapkan kembali ide penfaktoran yang telah \\
& diujinya dengan menemukan 26 bangun datar persegi panjang \\
& lain pada soal nomor 1 \\
& mampu menerapkan kembali ide yang yang telah diujinya \\
& pada soal nomor 2 dengan menemukan jawaban masing- \\
& masing lebih dari 3 bangun datar segitiga, datar jajar genjang, \\
& trapesium dan belah ketupat \\
\hline
\end{tabular}

Berdasarkan hasil tes dan wawancara di atas, kedua subjek penelitian melalui proses berpikir kreatif pada tahap persiapan, dengan gambaran aktifitas mental diantaranya: (a) mengumpulkan informasi dengan melakukan pememanggilan kembali pengetahuan- pengetahuan yang tersimpan pada memori jangka panjangnya seperti konsep, sifat matematika, dan soal-soal matematika yang relevan dengan masalah yang dihadapi dan melakukan interpretasi hubunganhubungan antara pengetahuan-pengetahuan yang relevan dengan tujuan yang akan dicapai, (b) membangun ide/gagasan dengan cara menjalin/mengaitkan pengetahuan-pengetahuan yang relevan dengan masalah pada TPMK, (c) menemukan cara prosedural, (d) mengimplementasikan cara coba-coba, (e) mengambil keputusan bahwa soal tidak dapat diselesaikan dengan cara coba-coba. Pada fase selanjutnya pada tahap persipan, keempat subjek melakukan proses berpikir keras. Pada fase ini subjek berpikir secara siklis dalam memikirkan ide baru untuk menyelesaiakan masalah yang dihadapai, dalam hal ini subjek melakukan proses berpikir yang serupa pada fase usaha menyelesaikan masalah namun dilakukan berulang kali, sampai subjek mengambil keputusan bahwa tidak memiliki ide yang lain untuk menyelesaikan masalahnya dan berhenti memikirkan masalahnya.

Pada tahapan inkubasi, kedua subjek melakukan proses berpikir yaitu: (a) berhenti memikirkan masalahnya atau tidak melakukan usaha berpikir untuk menyelesaikan masalahnya; (b) melakukan kegiatan tidak memikirkan masalahnya; kegiatan, bukan karena ingin melepaskan masalahnya. Demikian pula, keduanya 
melepaskan masalahnya, bukan karena keduanya melakukan kegiatan. Antara melepaskan masalah dan kegiatan, tidak terjadi hubungan sebab akibat. Pada tahapan ini: keempat subjek berbeda dalam hal kegiatan yang dilakukan dan lamanya mengalami inkubasi. Dari uraian di atas, disimpulkan bahwa pada tahap inkubasi, subjek dengan gaya kognitif reflektif berada dalam pikiran bawah sadar.

Pada tahap iluminasi, subjek penelitian melakukan proses berpikir: tiba-tiba menemukan ide/gagasan kunci dan menemukan ide/gagasan yang baru. Berkaitan dengan hal ini, kedua subjek penelitian belum meyakini sepenuhnya kebenaran idenya. Transisi dari inkubasi ke iluminasi hanya ditemukan pada subjek reflektif yaitu saat ia melakukan aktifitas buang air. Sriraman mengungkapkan bahwa ilmuan menemukan terobosan pada saat tertidur, berjalan, atau kadang-kadang berbicara dengan orang lain tentang masalah yang dihadapi. Pendapat Sriraman ini sesuai dengan hasil penelitian yaitu pada subjek reflektif, subjek ini menemukan idenya secara tiba-tiba saat melakukan kegiatan lain saat diberikan tes TPMK.

Hasil penelitian ini juga menjelaskan bahwa kedua subjek melakukan proses berpikir yaitu menguji ide dan mengimplementasikan idenya. Temuan tersebut menegaskan bahwa proses berpikir seseorang pada tahap illuminasi akan disusul oleh verifikasi. Dengan kata lain, setelah ilmuwan menemukan ide atau gagasan pada saat iluminasi, maka ia memverifikasi idenya dengan cara: mencari koherensi dengan hasil penelitian ilmuwan lain yang sesuai dengan substansi permasalahannya; matematika; keyakinannya dengan cara menurunkan bukti formal. Perbedaan terletak pada: pendekatan yang dilakukan kedua subjek dalam memverifikasi idenya adalah mencari koherensi dengan jawaban yang telah diperoleh sebelumnya (Setyana, 2019).

Subjek dengan gaya kognitif reflektif mengimplementasikan idenya dengan banyak jawaban benar, sedangkan subjek impulsif cenderung lebih sedikit dan kurang akurat. Hal ini sejalan dengan temuan Warli (2014) yang melaporkan bahwa kemampuan berpikir siswa reflektif dalam memecahkan masalah matematika cenderung tinggi. Dalam perencanaan pemecahan masalah cenderung rendah. Pada tahap pelaksanaan melaksanakan pemecahan masalah cenderung tinggi. Dalam melihat kembali fase, sangat berhati-hati dalam melaksanakan tahap (uji coba lebih dulu), mempertimbangkan berbagai aspek sehingga mereka memperoleh jawaban 
yang jauh lebih sedikit tapi benar. Siswa reflektif cenderung untuk memeriksa hasil karyanya. Sedangkan kemampuan Berpikir siswa impulsif dalam memecahkan masalah matematika cenderung sangat rendah. Dalam perencanaan pemecahan masalah cenderung sangat rendah dan pada tahap pelaksanaan melaksanakan pemecahan masalah cenderung rendah. Dalam melihat kembali fase, kurang ketepatan dalam fase (uji coba kurang) mengeksekusi, bergegas melalui masalah, sehingga mereka memiliki lebih banyak jawaban, tetapi sering yang salah. Siswa impulsif cenderung tidak memeriksa hasil karyanya. Hal itu sejalan dengan temuan Warli (2010) yang menyatakan bahwa perbedaan siswa reflektif dan siswa impulsif dengan tabel sebagai berikut:

Tabel 5 Perbedaan Siswa Reflektif dan Impulsif

\begin{tabular}{lll}
\hline \multicolumn{1}{c}{ Siswa Reflektif } & \multicolumn{1}{c}{ Siswa Impulsif } \\
\hline - Untuk menjawab digunakan waktu lama & - Cepat memberikan jawaban tanpa \\
- Jawaban lebih tepat (akurat) & - mencermati terlebih dahulu \\
- Reflektif terhadap kesusastraan & - Tidak menyukai jawaban masalah \\
- IQ tinggi & yang analog \\
- Menyukai masalah analog & - Sering memberi jawaban salah \\
- Berpikir sejenak sebelum menjawab & - Menggunakan hypothesis-scaning; \\
- Kelainan dari segi kognitif & yaitu merujuk pada satu \\
- Menggunakan paksaan dalam & kemungkinan saja \\
- mengeluarkan berbagai kemungkinan & - Pendapat kurang akurat \\
- Serargumen lebih matang & - Kurang strategis dalam \\
\hline
\end{tabular}

Pada penelitian ini, ditemukan pula bahwa kedua subjek melibatkan berpikir konvergen, berpikir logis, berpikir sistematis, berpikir analitis, berpikir divergen, berpikir kritis, metakognisi, dan intuisi. Berpikir konvergen, logis, sistematis, dan analitis, digunakan pada saat mencari koherensi antara soal yang pernah dijumpai dengan TPMK, menetapkan atau memilih fakta-fakta yang relevan, menguji dugaan-dugaan, dan mengimplementasikan ide. Berpikir divergen digunakan pada saat menemukan masalah, mengumpulkan informasi yang terkait, melakukan dugaan, dan membangun ide. Berpikir kritis digunakan pada saat menguji ide dan solusi. Metakognisi digunakan pada saat menyadari ketidakmampuannya. Intuisi digunakan pada saat menduga ide-ide. Temuan dalam penelitian ini khususnya fase ketiga pada tahap persiapan, juga sejalan dengan pandangan yang menyatakan bahwa kreativitas matematika adalah proses perumusan hipotesis mengenai sebab 
dan akibat dalam situasi matematika, pengujian, dan pengujian ulang hipotesis dan membuat modifikasi, dan terakhir mengkomunikasikan hasil (Gunawan, 2016).

\section{Kesimpulan}

Berdasarkan hasil penelitian di atas, penelitian ini menyimpulkan bahwa subjek penelitian dengan gaya kognitif reflektif melalui semua proses berpikir yaitu dari tahap persiapan, inkubasi, illuminasi dan verifikasi. Sedangkan subjek impulsif tidak melalui proses inkubasi karena tidak memikirkan hal lain selain soal setelah menemukan idenya. Subjek dengan gaya kognitif reflektif menemukan idenya tanpa dipicu oleh keadaan sekelilingnya atau mengembangkan idenya untuk membangun cara baru dalam menyelesaikan masalah.

\section{Daftar Pustaka}

Dewi, M. A. C., Sujana, I. W., \& Putra, M. (2013). Pengaruh Model Pembelajaran Inkuiri Terbimbing Terhadap Hasil Belajar IPA Ditinjau dari Kemampuan Berpikir Divergen Siswa Kelas V SD. MIMBAR PGSD Undiksha, 1(1).

Gunawan, I., \& Palupi, A. R. (2016). Taksonomi Bloom-revisi ranah kognitif: kerangka landasan untuk pembelajaran, pengajaran, dan penilaian. Premiere educandum: jurnal pendidikan dasar dan pembelajaran, 2(02).

Herianto, H. (2019). Penerapan Metode Accelerated Learning for The 21st Century Dalam Meningkatkan Hasil Belajar Matematika Siswa. Delta: Jurnal Ilmiah Pendidikan Matematika, 7(2), 37-50.

Januariawan, I. W., Wijaya, I. K. W. B., Supadmini, N. K., \& Dewi, D. N. (2020). Pengembangan Keterampilan Berpikir Tingkat Tinggi Melalui Pendekatan Open-Ended. Cetta: Jurnal Ilmu Pendidikan, 3(2), 125-140.

Mulyana, A., \& Sumarmo, U. (2015). Meningkatkan kemampuan penalaran matematik dan kemandirian belajar siswa SMP melalui pembelajaran berbasis masalah. Didaktik, 9(1), 40-51.

Nasriadi, A. (2019). Profil Pemecahan Masalah Matematika Siswa SMP Ditinjau dari Gaya Kognitif Reflektif dan Impulsif. MAJU: Jurnal Ilmiah Pendidikan Matematika, 2(2).

Novita, R., Prahmana, R. C. I., Fajri, N., \& Putra, M. (2018). Penyebab kesulitan belajar geometri dimensi tiga. Jurnal Riset Pendidikan Matematika, 5(1), 18-29.

Prasetyowati, D., \& Kartinah, K. (2019). Berpikir Reflektif Mahasiswa Program Studi Pendidikan Matematika Universitas Pgri Semarang Ditinjau Dari 
Gaya Kognitif Field Dependent. Jurnal Silogisme: Kajian Ilmu Matematika dan Pembelajarannya, 3(2), 43-47.

Purnomo, D. J., Asikin, M., \& Junaedi, I. (2015). Tingkat Berpikir Kreatif Pada Geometri Siswa Kelas VII Ditinjau Dari Gaya Kognitif Dalam Setting Problem Based Learning. Unnes Journal of Mathematics Education, 4(2).

Sari, A. P., Ikhsan, M., \& Saminan, S. (2017). Proses berpikir kreatif siswa dalam memecahkan masalah matematika berdasarkan model Wallas. Beta: Jurnal Tadris Matematika, 10(1), 18-32.

Setyana, I., Kusmayadi, T. A., \& Pramudya, I. (2019, October). Problem-solving in creative thinking process mathematics student's based on their cognitive style. In Journal of Physics: Conference Series (Vol. 1321, No. 2, p. 022123). IOP Publishing.

Simbolon, A. (2019). Peningkatan Kemampuan Koneksi Matematis Siswa melalui Pembelajaran Kontekstual dan Kooperatif Tipe Stad. Jurnal THEOREMS (The Original Research of Mathematics), 4(1).

Syawahid, M., \& Nurhardiani, N. (2018). Identifikasi Kemampuan Berpikir Formal Siswa SMA dalam Menyelesaikan Masalah Matematika ditinjau dari Gaya Kognitif. Suska Journal of Mathematics Education, 4(1), 17-26.

Warli. 2010. Kemampuan Matematika Anak Reflektif dan Anak Impulsif. Prosiding Seminar Pend. Matematika UMM Malang, 30 Januari 2010. 590-602.

Warli, W. (2014). Kreativitas Siswa SMP yang Bergaya Kognitif Reflektif atau Impulsif dalam Memecahkan Masalah Geometri. Jurnal Pendidikan dan Pembelajaran (JPP), 20(2), 190-201. 